\title{
HOXC11 wt Allele
}

National Cancer Institute

\section{Source}

National Cancer Institute. HOXC11 wt Allele. NCI Thesaurus. Code C97575.

Human HOXC11 wild-type allele is located in the vicinity of $12 q 13.13$ and is approximately $3 \mathrm{~kb}$ in length. This allele, which encodes homeobox protein Hox-C11, plays a role in embryologic pattern formation. 